\author{
Graduate Institute of \\ International and Development Studies Working Paper \\ No: 01/2014
}

\title{
Merger control procedures and institutions: A comparison of the EU and US practice
}

\author{
William E. Kovacic \\ George Washington University \\ Petros C. Mavroidis
}

The European University Institute (EUI)

Damien J. Neven

Graduate Institute of International and Development Studies

\begin{abstract}
The objective of this paper is to discuss and compare the role that different constituencies play in US and EU procedures for merger control. We describe the main constituencies (both internal and external) involved in merger control in both jurisdictions and discuss how a typical merger case would be handled under these procedures. At each stage, we consider how the procedure unfolds, which parties are involved, and how they can affect the procedure. Our discussion reveals a very different ecology. EU and US procedures differ in terms of their basic design and in terms of the procedures that are naturally associated with these alternative designs. On the one hand, there is a single investigator and decision maker operating under a symmetric mandate in the EU and on the other hand, an investigation and settlement operating under the threat of a court decision in case of challenge only in the US. The EU has developed numerous procedures and has granted extensive rights to the parties in the context of these procedures in order to provide some guarantee that the Commission's role as investigator and decision maker at first instance is not abused. By contrast, the US procedures appear to be rather informal, the balance in the investigation and evaluation of the merger being provided by the credible threat of a court decision. With a strong federal government that has extensive competences for regulation, merger control on competition grounds is subject to the additional public interest test of regulators in the US. Such additional control is weak in the EU, which has more limited competences for regulation. In addition, both the executive and the legislative powers are more fully developed at the federal level in the US. Both the executive power and the legislative seem to be in position to wield greater influence on enforcement in the US than is the case in the EU.
\end{abstract}

(C) The Authors.

All rights reserved. No part of this paper may be reproduced without the permission of the authors. 


\title{
Merger control procedures and institutions: A comparison of the EU and US practice
}

\author{
William E. Kovacic, \\ Petros C. Mavroidis, \\ and \\ Damien J . Neven*
}

J anuary 2014

J EL Classification: K21, K40, K4 *George Washington University; The European University Institute (EUI); and the Graduate Institute of
international and development studies, (IHEID) respectively. For very helpful discussions and comments
we are grateful to Simon Baxter, Fanis Christoforou, Thomas Deisenhofer, Fred Depoortere, Carles
Esteva-Mosso, Assimakis Komninos, Greg Langus, Mel Marquis, Kirtikumar Mehta, Giorgio Monti, Gil
Ohana, Andreas Reindl, and Wouter Wils. 


\begin{abstract}
The objective of this paper is to discuss and compare the role that different constituencies play in US and EU procedures for merger control. We describe the main constituencies (both internal and external) involved in merger control in both jurisdictions and discuss how a typical merger case would be handled under these procedures. At each stage, we consider how the procedure unfolds, which parties are involved, and how they can affect the procedure. Our discussion reveals a very different ecology. EU and US procedures differ in terms of their basic design and in terms of the procedures that are naturally associated with these alternative designs. On the one hand, there is a single investigator and decision maker operating under a symmetric mandate in the EU and on the other hand, an investigation and settlement operating under the threat of a court decision in case of challenge only in the US. The EU has developed numerous procedures and has granted extensive rights to the parties in the context of these procedures in order to provide some guarantee that the Commission's role as investigator and decision maker at first instance is not abused. By contrast, the US procedures appear to be rather informal, the balance in the investigation and evaluation of the merger being provided by the credible threat of a court decision. With a strong federal government that has extensive competences for regulation, merger control on competition grounds is subject to the additional public interest test of regulators in the US. Such additional control is weak in the EU, which has more limited competences for regulation. In addition, both the executive and the legislative powers are more fully developed at the federal level in the US. Both the executive power and the legislative seem to be in position to wield greater influence on enforcement in the US than is the case in the EU.
\end{abstract}




\section{INTRODUCTION}

The objective of this paper is to discuss and compare the role that different constituencies play in US and EU procedures for merger control. We attempt to highlight (some of) the key features of the procedures and characterise the relevant differences and commonalities.

The first part of the paper sets the scene by describing the main constituencies involved in merger control in both jurisdictions. We consider both external parties, including the merging parties and other interested parties like competitors and customers and other institutions (like the member states, the legislative and the regulatory agencies) but also the internal dynamics. With respect to the internal dynamics, we explicitly consider the role played by various internal constituencies, in particular the role played by economists, attorneys and the decisions makers.

The second part of the paper takes a practical approach and discusses how a typical merger case would be handled under these procedures. At each stage, we consider how the procedure unfolds, which parties are involved, and how they can affect the procedure.

Overall, the following observations could be made:

First, there is simultaneous enforcement of the merger provisions in the US by the States as well as by the Federal agencies. In addition, some regulatory agencies also have jurisdiction to review mergers under a different (public interest) standard and the interactions among agencies with overlapping jurisdictions affect the review process in various ways. By contrast, the Commission is the sole enforcer of the EU merger provisions and the influence other regulatory agencies on EU merger reviews is limited. Public interest considerations thus play a less important role in EU merger reviews. It is also striking that since member states have no role in enforcing the merging regulation, 
merger control is actually more centralised in the EU than the US, despite the fact that the EU institutional construction falls short of a full federal structure.

Second, the merging parties, as well as interested third parties, have fewer rights in the US (right to be heard, right of access to the file). More generally, the EU procedure can be characterized as one in which the basic design of having one agent as investigator and decision maker is compensated by extensive (but cumbersome) procedural rights for the parties.

By contrast, the US procedure takes place like an administrative procedure, under the threat of a court procedure. The threat of an independent decision in case of disagreements acts as a discipline on the agency (so that parties do not have to be given extensive but occasionally cumbersome procedural rights). Overall, the US thus relies more on incentives and the EU relies more on rules to ensure a balanced procedure.

Third, EU merger control is symmetric, in the sense that the Commission has to show either that the merger is anti-competitive or that it is not (with the same standard of proof) and both decisions can be appealed. By contrast, the US procedure is asymmetric, as a decision not to pursue a case or to accept commitments cannot be appealed in Court. In those circumstances, there is little cost for the agencies in being lenient. Whether the US agencies have been lenient relative to the EU is not an issue on which we take a view. The recent evidence put forward by Kwoka (2012) ${ }^{1}$ suggesting that prices do increase on average for a sample of mergers that have been allowed by the agencies would of course support the view that agencies have responded to this asymmetric incentive.

Fourth, regarding decision making, we find that the form of the US enforcement institutions (with the Department of Justice functioning as an agent of the executive branch, and the Federal Trade Commission operating as an agent of the Congress)

\footnotetext{
${ }^{1}$ Kwoka (2012), Does merger control work, A retrospective on US enforcement actions and outcomes, Northeastern University, mimeo
} 
makes the US system more amenable to political influence than the EU. In the EU, incentives are such that (limited) influence is exercised by member states pursing national interests. Still, instances in which the possibilities for political influence have been used in practice to affect decision making outcomes seem to be rare in either jurisdiction. In addition, the mandate is more focused in the US, the decision makers have a stronger background and competence in competition law and economics and will be more concerned about their future career in competition enforcement. The competition Commissioner, being part of the college, spends a significant share of his time on issues unrelated to enforcement and will not be worried about his legacy to the same extent (at least with respect to his career prospects)

Fifth, there are important differences in the development of the procedure; there appears to be considerably more flexibility in the timing of the procedure in the US (in particular after a second request). There is no sharp dichotomy between two phases as in the EU and the criteria for accepting remedies is the same, independently of whether they are considered before or after a second request. There are also striking similarities in the internal organisation. For instance, the economists provide an independent recommendation to the decision maker in all three institutions (DOJ, FTC and EU Commission).

\section{THE CONSTITUENCIES}

The EU has had a notification system since the adoption of the (original) merger regulation in 1989.2 The Commission is the only authority in charge of implementing the regulation, subject to a system of referral to (and from) member states ${ }^{3}$. This section considers the various constituencies involved in merger control in both jurisdictions.

\footnotetext{
${ }^{2}$ Commission Regulation 139/2004, OJ of 29J anuary 2004, pp24ff, amending Reg. 4064/ 1989 OJ L/ 395 of December 30, 1989.

3 This is further discussed below in the section on external constituencies.
} 


\subsection{THE CONSTITUENCIES IN EUROPE}

We discuss internal and external constituencies in turn.

\subsubsection{The internal constituencies}

Internal constituencies that play a role in merger proceedings include (in no particular order)

(i) the case team in charge of the investigation and its direct hierarchy (Head of Unit and Director);

(ii) the Deputy Director General (DDG) in charge of merger control and his/her own supporting staff;

(iii) the Director of the policy directorate (a horizontal directorate within DG COMP);

(iv) the Director General (DG) of the Directorate General for Competition (DG COMP);

(v) the Competition Commissioner and his/her Cabinet;

(vi) the Legal Service;

(vii) the Hearing Officer (HO);

(viii) the Chief Economist (CE) and his/ her team;

(ix) the other Commission services; and, finally,

(x) the College of Commissioners (and their respective cabinets).

We will highlight the role played by these various constituencies as we discuss the various stages of the procedure but a few general remarks may be useful at the outset. 
Whenever a potential case is brought to the attention of the Commission, a 'case team' will be assembled by the responsible Head of Unit and Director and a 'case manager' will be chosen ${ }^{4}$. DG COMP has an organisation according to sectors ${ }^{5}$ (so that each Directorate is responsible for a number of sectors), and within each Directorate, according to instruments (merger, antitrust, state aid), and there is no ambiguity regarding internal jurisdiction ${ }^{6}$. The investigation is undertaken by the case team in collaboration with the Chief Economist (more on this below). The case team will have up to 5 or 6 members (sometimes more) in significant cases, with different degrees of experience ${ }^{7}$.

The responsible Head of Unit and Director supervise the investigation and will be responsible for the drafting of notes, ultimately addressed to the Cabinet and the Commissioner. These notes will be prepared in the anticipation of significant and formal decisions and ahead of meetings with the parties. They will summarise the main steps of the investigation, the evidence that has been gathered and present options for a decision. The notes will be first discussed with the DDG (Deputy Director General) for mergers and his/her staff, and then with the senior management of DG COMP (including the Director General, the Director for Policy and the Chief Economist). These notes will ultimately be provided to the Cabinet of the Commissioner and the Legal Service. Informal (internal) contacts may of course take place before the notes are forwarded, in particular with the Legal Service in order to anticipate its position. General orientations on the case, and decisions are then taken in the context of a

\footnotetext{
4. Each Directorate is composed of a number of units (under the responsibility of a Head of Unit). The case manager could be the Head of Unit but does not have to be. Large units with a heavy merger case load will have several case managers.

5 Except for three horizontal directorates, namely the policy directorate, the cartel directorate and the state aid directorate responsible for some state aid instruments.

6 DG COMP used to have a different organisation, such that a specialised unit, the Merger Task Force, reviewed all mergers. The change of structure (implemented on July 1,2003) was part of the reforms implemented by Commissioner M. Monti after the annulment of a number of merger decisions by the European Courts (including Airtours, TetraLaval/ Sidel and Schneider/ Legrand). What prompted this change is arguably the perception that the work of the Merger Task Force was subject to insufficient oversight and that the Merger Task Force had developed a prosecutorial attitude (which is illustrated by the fact that, according to the Airtours J udgment, it has used evidence selectively and more anecdotally by the fact it had adopted a logo in the shape of a sheriff badge with a shark inside).

${ }^{7}$ When a large case team is required, additional staff can be allocated from other merger units or other units dealing with the same market but different instruments (for instance, civil servants working on state aids to the telecom industry could be allocated to a telecom merger).
} 
meeting in which the case team and the DG COMP hierarchy present the issues and options and in which the $\mathrm{CE}$, the Legal Service and the $\mathrm{HO}$ (to the extent required) are invited to express their views.

The Director for Policy is in charge of organising (peer review) panels (an internal review mechanism which is further discussed below), and he also reports on the outcome of the panel (together with the chairman of the panel) to the Commissioner.

Decisions are taken by the College of Commissioners (who meet on a weekly basis). Proposals for decisions need to be forwarded to the Cabinets of the various Commissioners a few days in advance, so that they can be discussed among Heads of Cabinets. All Phase I decisions ${ }^{8}$ are however delegated by the College to the competition Commissioner. It is very rare for Commissioners to discuss a proposed decision in the context of their weekly meeting but it is reported to occur on occasions ${ }^{9}$.

The associated services (which are in charge of the sectors in which the merger is taking place $^{10}$ ) are invited to comment on draft decisions to open a Phase II investigation, as well as final decisions regarding the approval and/ or rejection of the notified merger in Phase II. Their comments are not binding but might affect the view of the Commissioners in charge of these directorates. In order to avoid potential discussions at the level of the College, DG COMP thus naturally tries to accommodate comments from the associated services. The other Commissioners can be expected to defend some principles associated with their own competences, for instance the competitiveness of European firms in the case of DG Enterprises, or the exercise of some regulatory or industrial policy in the case of DGs with sectoral competences. More prosaically,

\footnotetext{
8 As discussed in detail below, the Commission can clear a merger after an initial review (Phase I) or open an investigation (Phase II).

9 According to Neven, Nuttal and Seabright (Merger in daylight, CEPR, 1994), a discussion took place regarding the proposed transaction between Aerospatiale, Alenia and de Havilland. There is no systematic source of public information on such discussion.

10 DG ECFIN is always consulted. The involvement of DG ENTERPRISE is not systematic but frequent. These services used to have dedicated Units to review of the proposed decisions. These units have been dissolved in the middle of last decade. There is thus currently less scrutiny from other services than in the earlier years of enforcement of the merger regulation.
} 
Commissioners could be expected to represent the interest of the member states that they originate from and governments of third countries (like the US) can make representations to the Commission's president ${ }^{11}$. Still, the threat by the associated services of triggering a discussion at the level of the Commission is often not credible as the decision by their own Commissioner to trigger a discussion will be affected by many considerations. In general, Commissioners will be concerned about interfering with the competence of their colleagues as it might lead to interference in the exercise of their own competences in the future. Decision making in the college can thus broadly be described as a tacit agreement not to interfere in the context of repeated interactions. It is only in extreme circumstances that strong objections will be raised ${ }^{12}$, for instance where important principles or interests are at stake and when the incentives to coordinate are generally weaker (for instance, towards the end of the Commission's mandate). The competition Commissioner thus enjoys a fair amount of discretion at the level of the College.

Since the Treaty of Lisbon, the College of Commissioners is appointed by the European Council and the European Parliament has a veto right over its appointment. The proposed Commissioners are heard by the Parliament individually but the Parliament votes on the Commission as a whole and not on individuals. Commissioners typically have a background in politics in a member state and often have had senior position in the executive branches of government, but not necessarily in an area related to competition enforcement. Recent Commissioners had no prior background in competition law or economics.

\footnotetext{
${ }^{11}$ This is reported to have occurred for instance in the Oracle/ Sun transaction (M.5529).

12 See Cabral (2005), An Equilibrium approach to international merger policy, International Journal of Industrial Organisation, 23. 739-751), for a model in which coordination breaks down when the parties have large stakes. The recent decision to allow the acquisition of Olympic by Aegean on the basis of a failing firm defence (see IP/13/927) could be seen a one in which wider considerations may have played a significant role given the very strict conditions for the application of such a defence (such that the assets would have to exit the market in the absence of the transaction and such that some demonstrable efficiency benefits are required).
} 
It is worth emphasizing that the European Council, by construction, does not have a strong ideological focus; it reflects the ideological diversity of the governments in charge in the member states at the time at which the Commission is appointed. Even if the diversity may sometimes narrow (in particular, as the orientation in large members states may matter more than in others), it is unlikely that a focused ideological orientation will prevail at any point in time. As a consequence, the Commissioners that will be appointed by the Council are unlikely to have a strong ideological identity, in particular those in charge of key directorates like Competition. The Commissioners will not be perceived to be accountable to the political parties that they were originally associated with (either at the European or national parliaments).

Even if Commissioners can be reappointed, they would typically change competences in the event of a reappointment ${ }^{13}$. If Commissioners leave the Commission, they will also typically not pursue a career in competition law or economics; they might return to domestic politics or join the private sector in senior advisory positions. As a consequence, Commissioners will not be concerned about their standing among senior competition practitioners and enforcers. The possible annulment of a decision by the Courts, although significant, may thus not be a prime concern for the Commissioner ${ }^{14}$. The public perception that competition problems are being tackled and solved may matter more.

A few additional words on two specific constituencies, namely the Hearing Officer and the Chief Economist, may also be useful at the outset, given the independence that they enjoy and accordingly the role that they play (at least potentially) in ensuring balanced and effective procedures.

\footnotetext{
13 There is no Commissioner who has held two full terms in charge of Competition. Commissioner Van Miert is the only one who held that position for more than one term, first as part of the Delors III Commission (from 1993 to 1995) and the Santer Commission until its collective resignation in 1999. However, the Delors III Commission had a shorter term in order to align the mandate of the Commission with that of the Parliament (as part of the implementation of the Treaty of Maastricht).

14 In particular, since the introduction of the fast track procedure for the review by the General Court, it is now more likely that a court judgement will be rendered during the term of the Commissioner.
} 


\section{The Hearing Officer}

The $\mathrm{HO}^{15}$ is appointed by the Commission ${ }^{16}$, and is functionally 'attached' to the Commissioner for Competition ${ }^{17}$. The HO is thus independent from DG COMP since he does not report to a senior civil servant within DG COMP. His evaluation and promotion are determined by the Commissioner but the $\mathrm{HO}$ is nonetheless supposed to act independently (of the Commissioner) when performing his function ${ }^{18}$.

The independence of the $\mathrm{HO}$ is further underscored in the Preamble to the Decision ${ }^{19}$, which states that, in order to ensure the effective exercise of procedural rights, responsibility for the protection of these rights must be entrusted to an independent person; furthermore, the Preamble 20 calls on the $\mathrm{HO}$ to operate as an independent arbiter.

The essential function of the $\mathrm{HO}$ is thus to safeguard the effective exercise of all procedural rights of the parties involved throughout competition proceedings before the Commission ${ }^{21}$. To exercise this function, the powers of the $\mathrm{HO}$ are quite extensive and include the right to decide:

(a) On complaints that the effective exercise of procedural rights has been denied or undermined ${ }^{22}$. The Preamble to the Decision underscores that the right to be heard is a 'fundamental right' in the EU legal order23;

(b) On whether 'third persons' (this term being understood in light of the implementing regulation, e.g. competitors, customers or consumer

\footnotetext{
15The role of the Hearing Officer (HO) in competition (both merger as well as antitrust) proceedings is explained in Decision 2011/695., OJ L 275/29ff. of 20 October 2011. The HO was created already in 1982. The 2011 Decision aims at clarifying and strengthening its role, see Wils, (2012) The Role of the Hearing Office in Competition Proceedings before the European Commission, World Competition: Law and Economics Review, 35(3).

16 Art. 2.1 of the Decision

17 Art 2.2.

18 Art 3.1

19 Rectal 3

20 Recital 8

21 Art 1.2 .

22 Art 3.7

23 Recital 2
} 
associations) will be heard, provided that they have shown sufficient interest to do so. When deciding on this issue, the HO must first consult with the responsible Director in DG Competition ${ }^{24}$. This provision could at first sight be perceived as casting doubt on the independence of the HO. However, the obligation of the $\mathrm{HO}$ is simply to consult with DG Competition, and not to defer to its conclusions;

(c) On violations regarding access to file for interested parties following the issuance of a statement of objections ( $\mathrm{SO})^{25}$. The obligation to grant access to file is further specified, and includes issues such as the question whether a particular document has been covered/discussed in the proceedings etc. The HO can decide to give access to parts of the file to interested parties, and even 'stop the clock' if, for example, the deadlines set by the Commission were too short/ unrealistic;

(d) On the treatment of confidential information submitted to the Commission ${ }^{26}$.

To be in a position to effectively undertake the mission that he/ she is entrusted with, the $\mathrm{HO}$ itself must have un-inhibited access to file ${ }^{27}$. The $\mathrm{HO}$ is responsible for organizing an oral hearing (if requested by the parties) in order to ensure that procedural rights of all those involved have been respected ${ }^{28}$.

The HO will issue an interim ${ }^{29}$, and a final ${ }^{30}$ report where he/ she will state whether the procedural rights have been respected throughout the proceedings before the Commission. This report will be provided to the other Commissioners together with the proposed decision.

\footnotetext{
${ }^{24} \operatorname{Art} 5.2$

25 Art 7

26 Art 9 .

${ }^{27}$ Art 3.3.

${ }^{28}$ Art 10-13

29 Art 14.

30 Art 16.
} 


\section{The Chief Economist and his team}

The position of Chief Economist was created by Commissioner Mario Monti, allegedly as part of the reform that he implemented following the annulment of three merger prohibition decisions by the European Court of First Instance (namely the Airtours/First choice, Schneider/Legrand and the Tetra Laval/Sidel decisions) ${ }^{31}$. These Court judgments pointed to a level of economic analysis that was clearly unsatisfactory in the eyes of the Court, and to shortcomings in the handling of evidence (which, in the Court's view, was unbalanced). The Chief Economist and his/ her team were thus meant to improve the economic analysis undertaken by DG COMP but its mandate was also designed to provide him/her with (some) independence, thereby providing a mechanism of checks and balances. As emphasized by Roeller and Buigues (2005) ${ }^{32}$, the CE thus has both a support, as well as a "checks and balances" function.

Formally, the CE reports to the Director General of DG Competition. His/her independence from DG Competition is guaranteed, to some extent, by the fact that he/ she is a temporary agent, who is thus not concerned by career motives within the Commission ${ }^{33}$. The $\mathrm{CE}$ has a team which has been progressively enlarged from originally about 10 , to 25 members.

In terms of the support function, the $\mathrm{CE}$ will provide support to the case team upon their request. The $\mathrm{CE}$ can also make a request (to the DG) in order to be involved in a case. The CE (or his/ her representative) participates in the internal management meetings in which cases are allocated. The practice has evolved in such a way that the $\mathrm{CE}$ and his team are involved in the vast majority of significant merger cases. The internal organization is thus such that the CE works together with the case team.

\footnotetext{
31 See e.g. Gonzalez-Diaz, E., 2012, The effect based approach in EU merger control, in Bourgeois J. and D. Waelbroeck (eds), Ten years of effects-based approach in EU competition law, state of play and perspectives, Bruylant, Brussels..

32 Roeller, L.-H and P. Buigues, (2005), The office of the chief competition economist at the European Commission, Global competition review, Handbook of competition economists, 3-12

$33 \mathrm{He} /$ she might of course then be concerned about other career motives, in particular in consultancy after he/she leaves the Commission.
} 
Regarding the 'checks and balances' function, the CE participates in the weekly meeting with the Commissioner (independently of DG Competition), and provides independent advice in the course of these meetings (see Roeller and Buigues, 2005). The CE also writes a final advice to the Commissioner on the decision to be taken in particular cases and this final advice is available to the other members of the College. It is understood that the set of case for which a final advice is provided and the conditions under which it is provided have been further specified, but these rules are not publicly available. Interestingly, it would appear that there is no clear rule on whether the final advice should be systematically shared with other Commissioners (unlike what happens with the report of the Hearing Officer).

When the Chief Economist Team was created, it was often perceived to act as a restraint on the case teams, imposing different standards in terms of evidence and reasoning and overall making it more difficult for them to bring cases. This perception has probably become less acute over time as the CET has developed evidence that has proved critical to bring cases. There is also a large amount for discretion for the $\mathrm{CE}$ in setting priorities and those can change over time with the identity of the CE. In any event, there is a delicate balance to be found between the support and checks and balances functions that can shift over time ${ }^{34}$.

\subsubsection{External constituencies}

External constituencies include the member states, the parties and their advisors and other interested parties.

There are various ways in which the member states affect the procedure ${ }^{35}$. First, the member states can seek the referral of a merger cases; there are two mechanisms to

\footnotetext{
34 There is of course a risk that members of the team, who are more permanent, will be captured by the case teams and respond to internal career motives, independently of the CE. The independence and identity of the CE function could also be impaired by tradeoff across cases (such that support in one instance against better judgment is used in order to obtain reciprocal support in another).

35 Of course, member states play an important role in the control of mergers that do not have a community dimension and their approach may sometimes differ. The Commission has recently created a working group in the context of the European Competition Network to foster convergence in assessments.
} 
achieve this. First, prior to notification, the notifying parties may draw the attention of the Commission to markets in which the transaction has effects that are clearly national in scope (Art 4(4) of the merger regulation). The Commission may then decide to refer part of the case to the national authority concerned for the application of relevant national merger laws. Second, post notification, a member state may require the referral of a case (or part of it), for the application of national laws if it is anticipated that the members state is (or includes) a distinct relevant geographical market in which a competition concern may arise (Art 9). The decision whether to refer the case is taken by the Commission and does not hinge on the existence of a specific relevant geographical market. According to Deisenhofer (2013) ${ }^{36}$, these referral procedures do not give rise to significant conflicts ${ }^{37}$ but some cases (like the Art 9 referral of the ProSiebenSat1/RTL merger to the Germany and Austria, or the Veolia/Trandev Art 9 referral to France and the Netherlands) have been subject to an intense debate.

Second, the member states can impose remedies in addition to those envisaged by the Commission, on public interest grounds, according to Art 21(4). Prudential rules, security and the plurality of the press are recognised as legitimate public interest grounds but others can be admitted by the Commission (upon request from the member states concerned). Some countries, like France (under the decree 1739/2005) have procedures to review mergers that raise public interest issues and appears to frequently impose additional (but minor) conditions ${ }^{38}$ which however do not interfere with the competitive assessment of the Commission (or the remedies accepted by the Commission) or indeed would not appear discourage transactions that have been notified. There is one instance, however, in which Art 21 gave rise to a conflict between

\footnotetext{
36 Deisenhofer, T., (2013), International cooperation in merger cases - an EU practitioner's perspective, in Philip Lowe and Mel Marquis, eds., European Competition Law Annual 2010: Merger Control in European and Global Perspective, Oxford: Hart Publishing, 227-242.

${ }^{37}$ The referral from one (or several) member states to the Commission is also possible under Art 4(5) and Art 22.

38 See Neven (2010), Ownership, performance and national champions, in Competition Law and Economics, A. Matutes and T. Moreira (eds), chapter 20, E. Elgar
} 
Spain and the Commission ${ }^{39}$. Faced with a bid for Endesa by E.On (a German firm), the Spanish government introduced a decree such that the bid would have to be reviewed by the energy regulator. The merger was cleared by the Commission ${ }^{40}$ but the regulator imposed stringent conditions and the bid failed. The Commission took a decision (under Art 21) ${ }^{41}$ declaring the conditions in breach in the merger regulation. When Spain failed to withdraw the conditions, the Commission lodged an action in front of the European Courts. The Commission prevailed ${ }^{42}$ but in the meantime, Endesa has been acquired by Acciona (a Spanish) firm and Enel ${ }^{43}$. Hence, it would appear that at least in this instance, a member state has been able to prevent a Commission decision from taking full effect. This however appears to be an isolated event.

Third, member states are invited to express their views in the context of the "Advisory committee on concentrations"; the opinion of the Committee is sought on all Phase II decisions and is published together with the final decision. The representatives of the member states in this committee come from the competition agencies (or more generally the institution in charge of merger control in the member states concerned). These representatives thus have frequent informal contacts with the Commission, for instance in the context of the European Competition Network. They are thus positively inclined, belonging to the same club of European enforcers. The opinion of the advisory committee is invariably supportive of the proposed decision but the proposal from the Commission can be adjusted in light of the debates with the member states. Finally, as mentioned above, Member states can also voice concerns at the level of the Commissioners, in particular with respect to wider issues.

\footnotetext{
39 See Buza, L. and E. Zaera Cuadrado, (2008) Application of Art 21 of the merger regulation in the E.On/Endesa case, Competition Policy Newsletter, 2, pp1-3

40 Case M 4110

${ }^{41}$ Case M4197

42 Case C-196/ 07, Commission vs Spain, J udgment March 6, 2008.

43 This merger was cleared by the Commission (M 4865).
} 
Overall, there is thus a mixed pattern and the member states would appear to play a significant role in instances in which they have important stakes but not necessarily on a routine basis.

The merging parties have extensive rights to be heard in the Commission procedure ${ }^{44}$. They have the right to a hearing in Phase II and the right of access to the file (after the Statement of Objections has been sent). The Commission, under its duty of due diligence, has the obligation to take into account the information that the parties submit voluntarily. The parties can have extensive contacts with the Commission during the investigation and according to the "Best practice on the conduct of EC merger proceedings", they should expect to have at least five state of play meetings.

The parties are also increasingly assisted by economic consultants in addition to their legal advisors ${ }^{45}$. The economic consultants often make stand-alone submissions in the procedure. These submissions are reviewed by the CET and when the CET undertakes its own work, it is naturally scrutinized by the economic consultants. Economists to economists meetings are sometimes organised to debate technical issues but the organisation of these meeting remains at the discretion of the Commission (and have been denied in some instances) ${ }^{46}$. Over the year, a very active community of specialised lawyers and economic consultants has developed around the Commission. Commission decisions and policy proposals are debated in numerous conferences and policy publications.

Other interested parties include the customers and the competitors but also sometimes local governments (for instance when a merger will lead to a relocation of activities). These parties play an important role in the Commission's procedure. The Commission's

\footnotetext{
44 These rights are defined in the merger regulation (Art. 18 Reg. 139/2004).

45 In difficult cases, the parties also often elect support from public affairs consultants. A number of firms have emerged in recent years, which often employ former officials. This has led to a complaint to the Ombudsman about conflict of interests, lodged by a number of NGOs. This complaint draws attention to individuals who have been active in merger control. The Ombudsman has $\begin{array}{lllll}\text { opened an investigation } & \text { in } & \text { February } & 2013 .\end{array}$ (http:/ / corporateeurope.org/ sites/default/files/ publications/ ombudsmancomplaint_commission_revolvi ngdoors.pdf)

46 A legal advisor to the parties and a member of the case team is typically present at those meeting to avoid the development of parallel streams of work.
} 
duty of diligence does not stop with the merging parties and extends to the voluntary submissions of these interested parties as well. In addition, the views of the interested parties will be sought in the context of the market investigation, the Commission can decide to provide them with a non-confidential version of the SO and they can be admitted to hearings (by a decision of the Hearing Officer, upon request). Hence, the interested parties have ample opportunities to make representations, to follow the results of the investigation and intervene at various points in the procedure. They also play an important role in the design and evaluation of remedies, as the Commission will seek their comments on whether proposed remedies are adequate (in the context of a "market test" of the remedies). The third parties (in particular the competitors) may then be in a position to act strategically and to leverage their position towards the merging parties (for instance, if they are interested in purchasing assets). Unlike what happens in the US, the comments on proposed remedies are not made public, which enhances the scope for strategic behaviour.

\subsection{THE CONSTITUENCIES IN THE US PROCEDURES}

The US merger control process differs from the EU regime in three major respects. First and most important is the multiplicity of entities that can enforce the merger control mandate of the US antitrust laws. Two national competition authorities - the Antitrust Division of the Department of J ustice (DOJ ) and the Federal Trade Commission (FTC) - share competence to enforce the chief US anti-merger mandate, Section 7 of the Clayton Act. ${ }^{47}$ State governments also have power to enforce Section 7. Merger review by the federal agencies does not oust the jurisdiction of the states, even when a transaction has broad national significance. If the federal agencies decide to clear a merger or accept a settlement that allows the merger to proceed, the state governments

\footnotetext{
4715 U.S.C. §18. This merger control provision was enacted in 1914 and modified substantially in 1950 by the Celler-Kefauver Act. In addition to its authority to enforce Section 7 of the Clayton Act, the FTC also can challenge a merger as an "unfair method of competition" under Section 5 of the Federal Trade Commission Act. 15 U.S.C. §45. The US courts have interpreted this provision to give the FTC power to reach conduct beyond the reach of the Clayton Act. Thus, in principle, the FTC could use Section 5 to block a merger that would not violate standards established under Section 7 of the Clayton Act, but the FTC seldom uses Section 5 as a distinctive basis for challenging mergers. On the diversification of the power to challenge mergers in the US antitrust system, see J . Robert Robertson \& Corey W. Roush, Procedural and substantive differences in merger challenges by different authorities in the United States, 58 Antitrust Bulletin 201 (Summer-Fall 2013).
} 
retain power to bring a Section 7 case to seek additional relief or block the deal entirely. ${ }^{48}$ Nor is involvement by public antitrust agencies, state or federal, dispositive. Even if the federal and state antitrust agencies stand aside or seek only limited relief, private parties (e.g., customers or rivals) have standing under the US antitrust laws to bring cases to enforce Section 7.49

The second noteworthy difference involves the merger control powers of sectoral regulators at the national and state levels. For example, the Federal Communications Commission (FCC) has authority under the Communications Act of 1934 to review mergers under a "public interest" test that encompasses, but is not limited to, consideration of a transaction's likely competition effects. DOJ and the FCC ordinarily review telecom mergers concurrently. Compared to instances in which DOJ reviews a merger on its own, the pendency of an FCC merger review gives DOJ important advantages when it seeks to block mergers or negotiate concessions. 50 Moreover, state public utility commissions enjoy substantive authority similar to the FCC's competence for deals that affect commerce within their state borders. Many state public utility laws establish public interest mandates that enable the public utility commission (PUC) to review and oppose mergers on competition grounds.

The third important variation between US and EU practice concerns the role of the courts. To block a proposed merger, the federal agency handling the case (the DOJ or

\footnotetext{
48 California v. American Stores Co., 495 U.S. 271 (1990). In the US system, states also have the ability to immunize mergers and other forms of business conduct from federal antitrust scrutiny by adopting legislation that (a) clearly articulates a purpose to displace the application of the antitrust laws and (b) creates a mechanism for the state to supervise actively the implementation of the competition-suppressing scheme. The availability of "state action" immunity has arisen recently in the Supreme Court's decision in Federal Trade Commission v. Phoebe Putney Health System, Inc., 133 S.Ct. 1003 (2013), where the Court withheld immunity because legislation adopted by the State of Georgia failed to clearly articulate a purpose to suppress competition in the review of hospital mergers.

49 To establish standing under the Clayton Act, competitor plaintiffs in merger cases face demanding requirements to show that their injury results from a reduction, rather than from an expansion, of competition. Cargill, Inc. v. Monfort of Colorado, Inc., 479 U.S. 104 (1986); Brunswick Corp. v. Pueblo Bowl-O-Mat, Inc., 429 U.S. 477 (1977). Nonetheless, private plaintiffs in several important cases have succeeded in obtaining injunctions to block proposed mergers. Perhaps the most notable example is Marathon Oil Company's successful effort in the early 1980s to ward off a hostile tender offer by Mobil Oil Corporation. Marathon Oil Co. v. Mobil Corp., 530 F. Supp. 315 (N.D. Ohio) (preliminary injunction granted), aff'd, 669 F.2d 378 (6 $6^{\text {th }}$ Cir. 1981).

50 The occasion for the FCC's review of mergers ordinarily consists of a request by the merging parties to transfer operating licences issued by the FCC. The FCC need not go to court to block a merger; it only needs to deny the transfer of a license. If the FCC denies a license transfer, the only recourse of the parties is to appeal the FCC's decision to the federal court of appeals, a process that can take several years to generate a decision. In the interim, the parties cannot complete the transaction.
} 
the FTC) must obtain an injunction from a federal court. ${ }^{51}$ Unlike the European Commission, the two national agencies lack authority to issue prohibition decisions for proposed mergers on their own accord. In Europe, judicial participation in merger control takes place only through appeals from the Commission decisions; in the US, judicial intervention is necessary to halt a transaction. In dealing with the DOJ and FTC, the merging parties know that, however strongly the agency believes a proposed deal is anticompetitive, the agency must persuade a federal district judge to enjoin the merger. The commitment of the parties to litigate disputed issues is a credible threat and an important influence on agency decision making.

The US courts have no role to play in decisions by the US federal agencies to clear mergers. Their responsibility also is very limited where DOJ or the FTC accept settlements that require divestitures or conduct remedies. The FTC must publish proposed settlements for notice and comment, but its final decision about the remedies to be adopted is not subject to judicial review. Where DOJ has filed a complaint to challenge a merger, it must obtain judicial approval through what is known as a Tunney Act proceeding. The Tunney Act requires the court to assess whether the proposed consent decree is in the public interest.52 For the most part, judicial review under this standard is relatively deferential to DOJ's assessment about settlement terms.

This section reviews the complex ecology of constituencies, inside and outside the agency, whose actions affect the implementation of the US merger control system. The section first describes the constituencies inside the two national competition agencies and then identifies players outside the DOJ and the FTC.

\footnotetext{
51 The FTC can invoke a more favorable legal standard than DOJ when it seeks an injunction to block a merger. As described more fully below, this difference arises from the operation of the FTC's administrative adjudication process. Section 13(b) of the FTC Act gives the FTC authority to seek injunctions to in federal court to block mergers or address other forms of anticompetitive conduct. 15 U.S.C. §53(b). This measure has been interpreted to require district courts to issue injunctions when the FTC has raised important issues worthy of fuller examination in the FTC's administrative process. See,e.g., FTC v. CCC Holdings, Inc., 605 F. Supp. $2 \mathrm{~d} 26$ (D.D.C. 2009). In such cases, the court would issue a preliminary injunction to enjoin the merger pending resolution of the issues in question in an FTC administrative trial. By contrast, DOJ has no administrative mechanism to adjudicate antitrust matters. This procedural difference and the degree to which it gives the FTC relatively greater ability to block deals are matters of continuing controversy.

5215 U.S.C. §16.
} 


\subsubsection{Constituencies inside the DOJ and the FTC}

DOJ and the FTC have notably different institutional architecture. The Antitrust Division is a relatively small part of an immense, diversified executive branch department. The Antitrust Division has an annual budget of approximately $\$ 160$ million, and its substantive mandate is limited to antitrust law and policy. The Antitrust Division is headed by a single Assistant Attorney General for Antitrust (AAG). The AAG is a political appointee who serves at the pleasure of the President. The entire Department of J ustice has an annual budget of roughly $\$ 23$ billion USD. In addition to antitrust, DOJ enforces a wide array of other laws (e.g., civil rights, federal criminal statutes) and represents the government in a broad range of matters. The DOJ is headed by the Attorney General, who also is a political appointee and serves at the pleasure of the President. The Antitrust Division prosecutes all of its cases, including challenges to mergers, in the federal courts.

The FTC is a multi-member administrative commission. The five members of the board are appointed for fixed seven-year terms and can be removed only for cause. Although the fixed terms of FTC commissioners give the agency insulation from direct executive branch intervention, the Commission is subject to greater influence from the US Congress than is the DOJ. The FTC also has a more diversified portfolio of responsibilities than DOJ. The Commission has three distinct policy mandates: antitrust, consumer protection, and privacy. Approximately 45\% of the FTC's $\$ 300$ million annual budget is devoted to competition law enforcement and other forms of policy making.

\section{Internal Constituencies Common to DOJ and the FTC}

DOJ and the FTC consist mainly of two groups of professionals: attorneys and economists. As a rough generalization, each group has a different culture and selfimage. The attorneys tend to envision themselves as prosecutors and derive professional satisfaction (and develop opportunities for greater mobility inside and outside their institutions) from the preparation and filing of cases. By contrast, the 
economists tend to view themselves as policy analysts dedicated to achieving the correct result, be it to intervene or to stand down. Economists as a group tend to regard the attorneys as less fully committed to attaining the best policy outcome and more inclined to bring cases in borderline situations.

The stereotypes set out above have a substantial element of truth, but require some qualification. Compared their counterparts to 40 years ago, DOJ and FTC attorneys are more attuned to conceptions of economically rigorous antitrust policy and less prone to litigate cases of doubtful merit. Since the early 1970s, the federal courts have embraced doctrines and perspectives that emphasize efficiency considerations and disregard noneconomic values. Cases that lack sound economic foundations run a genuine risk of rebuke in court - an outcome that degrades the professional stature of attorneys who worked on the failed litigation efforts. This development has led attorneys to develop at least a rudimentary understanding of core principles of industrial organization economics and to build cases that have greater economic coherence.

In the same period of time, economists also have descended somewhat from the higher moral ground of being the conservators of truth-seeking in antitrust analysis. The past four decades have witnessed a transformation of economic consulting in the United States - from a service sector once characterized by a few firms ${ }^{53}$ and a large number of sole practitioners (mostly on university faculties) to a large, organized enterprise featuring a substantial number of consultancies, many of which employ networks of academics in full-time teaching positions. The growth of these consultancies has tracked doctrinal and policy developments that have increased the significance of economic analysis in merger review. The economic consultancies closely resemble major law firms in billings, costs, and profitability. The imperative to meet budgets and income targets has made economists more willing to accept a wider range of representations - i.e., to behave more like attorneys. Experience inside a government antitrust agency in working on cases and testifying as experts gives economists human

\footnotetext{
53 For example, Charles River Associates originated in the late 1960s and early 1970s to provide assistance to IBM in defense of antitrust cases challenging its conduct in the mainframe computer market.
} 
capital that expands employment opportunities outside the civil service. The possibility of moving laterally to attractive private sector positions outside the government has made economists more willing to support cases - or, at least, to oppose them less vehemently - than they might have at an earlier time.

The DOJ and the FTC rely on the professional tension between economists and attorneys to improve quality control in merger review. In both agencies, economists reside in distinct operating units - the Economic Analysis Group (EAG) within DOJ and the Bureau of Economics (BE) within the FTC. From these platforms, the economists are assigned to work on merger review teams headed by attorneys. The DOJ and FTC economists work with the attorneys, but they do not work for them. The work of the agency economists is evaluated by economists, not by attorneys. This gives DOJ and FTC economists an important measure of autonomy. For each proposed enforcement decision, the economists prepare their own recommendations, which pass through their internal hierarchy (i.e., through the Deputy Assistant Attorney General for Economics or the Director of the Bureau of Economics) to the agency leadership (the Assistant Attorney General for Antitrust, or the FTC commissioners). As discussed more fully below, the EAG and BE are important quality control mechanisms within DOJ and the FTC, respectively ${ }^{54}$. Both agencies have come to depend heavily on the views of these economic units in determining whether a case is sustainable and is likely to withstand challenge in litigation in the federal courts. 55

The establishment of the separate economic units within DOJ and the FTC is not mandated by statute but instead is a matter of administrative discretion delegated to the agencies. Thus, the autonomy of the economists' teams is a matter of custom rather

\footnotetext{
54 According to Froeb, L., P. Pautler and L.-H. Roeller, (2009), (The economics of organizing economists, Antitrust Law J ournal, 76, p569-), there is greater integration of the work of economist and attorneys in the DOJ than in the FTC. It is not clear however that the difference is of great significance.

55 One of us (Kovacic) has observed instances in which the FTC relied too heavily upon BE to perform the quality control function in merger review. BE is well-suited to give an opinion on a merger's likely competitive effects, but economists are not trained to offer guidance about how specific litigation strategies will play out in the courtroom, or to give advice about the best sequencing for the presentation of evidence at a trial.
} 
than the product of a legal mandate. As such, it would be possible for the agencies to carry out restructurings that, in the extreme case, disbanded the independent units and relocated the economists within case handling teams. Because such a step would be so jarring a departure from past practice, it is unlikely that leadership of either agency would carry out such a reform. Congressional committees also carry out some oversight of significant agency reorganizations by requiring agencies to notify them in advance.

Each agency also has set up mechanisms within its community of attorneys to offer views independent of the recommendations of the merger case teams. In DOJ , uses its Office of the General Counsel and its Director of Litigation to offer views to the AAG about the disposition of merger matters within the Antitrust Division. In considering mergers, the members of the FTC receive a separate recommendation from the agency's General Counsel. The FTC Office of the General Counsel plays a major role in the litigation of merger cases in the federal courts and represents the Commission in all appellate litigation. These mechanisms generate additional opinions, beyond the recommendations of the merger case handlers and the agency economists, for the AAG and the FTC commissioners to consider in deciding how to address mergers.

Both DOJ and the FTC from time to time also have designated a team of economists and lawyers to perform the "devil's advocate" function and present evidence and arguments that the parties are likely to offer in a litigated proceeding. To be effective as a constraint upon agency decision making, the views of this adversary team must be assembled and presented well in advance of the decision to prosecute. If the adversary team offers its views close to the deadline for deciding whether to seek an injunction in court, the momentum that develops within the case team and inside the agency to challenge the merger may overwhelm cautions about weaknesses in theory or evidence.

\section{The FTC's Distinctive Internal Constituencies}

The FTC has two internal constituencies which lack parallels within DOJ. The first deals with governance. Unlike the Antitrust Division, which is led by a single decision maker, the FTC is headed by a five-member board, no more than three of whom may be 
members of the same political party. A decision to intervene in a merger case requires the vote of a majority of Commissioners who are eligible to participate. In the ordinary case, when there are no disqualifications, vacancies, or recusals, the agency's staff must persuade three of the five commission members to intervene. As described below, the parties typically have an opportunity to make presentations to each commissioner before the agency chooses a course of action.

Compared to leadership by a single AAG, the FTC's multi-member governance configuration has several implications for the merger control process. First, the need to engage five individuals in the decision to prosecute typically lengthens the process. The briefing of five persons (rather than one) and the formation of a consensus among the five tends to stretch the FTC's process beyond what one sees at DOJ. A second consequence is that the FTC's process is more prone to result in an inability to act than at DOJ . Without a majority, the Commission cannot act. There have been instances in which mergers have proceeded without FTC intervention because the Commission had only four participating commissioners, and the four members deadlocked 2-2 over whether to issue a complaint or accept a settlement ${ }^{56}$. Third, the political diversity requirement can inject somewhat greater stability into the agency's deliberations when presidential elections produce a regime change. In most circumstances, at least two members of the Commission will have party affiliations other than that of the President. The presence of appointees from other parties can temper efforts to make dramatic departures from past practice in merger control.

A second FTC internal constituency that has no DOJ counterpart derives from the agency's multi-function mandate. As noted above, the FTC is a policy conglomerate with three distinct "product lines" - antitrust, consumer protection, and privacy. The agency's consumer protection and privacy teams have no formal role in merger deliberations, but their presence within the FTC can influence, at least indirectly, the

\footnotetext{
56 There have been instances in which mergers have proceeded without FTC intervention because the board reaches an impasse over a specific course of action. For example, in 2001, the FTC reviewed a merger of General Mills and Pillsbury. One member of the FTC was recused, leaving four commissioners to deliberate. The commission deadlocked 2-2 over whether to accept behavioral remedies to resolve competitive overlaps.
} 
disposition of a proposed deal. Because of the breadth of the FTC's mandate, many firms engage in activities that fall within two or more of the Commission's policy domains. This creates opportunities for what might be called regulatory leveraging. The Commission might use the gatekeeping role established by the mandatory notification and waiting period requirements of the Hart-Scott-Rodino Antitrust Improvements Act (HSR) to extract concessions with regard to non-antitrust issues. The agency might suggest, for example, that it will more readily approve a company's proposed merger if the company agrees to adjust its data protection policies ${ }^{57}$. Alternatively, in bargaining for concessions concerning a merger, the Commission might remind the merging parties that they currently have consumer protection or privacy issues before the agency. If the parties take a hard line in the merger negotiations, the Commission may make life more difficult for them in non-antitrust matters involving the same firms. In these ways, consideration of a merger by a multi-function agency can present complications not present when a single-purpose entity (the DOJ Antitrust Division) is dealing with the merger 58 .

\subsubsection{Constituencies External to DOJ and the FTC}

A wide array of constituencies outside the federal antitrust agencies can be considered to be players in the merger review process. Some of these bodies participate more directly by conducting their own merger reviews (e.g., state governments) or appearing before the federal agencies to provide evidence (e.g., third parties such as customers or rivals of the merging parties). Other groups participate less directly -- for example, by applying political pressure upon the antitrust agencies to take a specific course of action.

\footnotetext{
57 One of us (Kovacic) observed intense discussions within the FTC during deliberations over Google's proposed acquisition of Doubleclick and Google's purchase of Admob. Some commissioners and staff within the FTC's privacy team wanted to require, through the second request, that Google provide information regarding its data protection policies. The agency did adopt this suggestion, which reflected a desire to use the mandatory merger review to gather information and, perhaps, obtain concessions regarding Google's privacy policies.

58 DOJ itself is a diverse multi-function institution. The Antitrust Division has a single-purpose (antitrust only) mandate.
} 


\section{State governments}

As we described above, state governments have standing to bring cases to enforce the federal anti-merger law, Section 7 of the Clayton Act. A decision by the federal agencies to stand down or to accept a settlement does not oust the jurisdiction of the states. When the federal agencies bring a lawsuit to block a merger, it is common to see state governments joining the complaint as plaintiffs. For example, in the recent lawsuit to enjoin the merger of American Airlines and USAirways, DOJ and various state governments filed the complaint jointly as co-plaintiffs.

The possibility of state participation is an important consideration in merger planning by DOJ and the FTC. Sometimes the federal agencies regard the participation of the states as helpful. States may be able to assist in developing evidence about local conditions with which they are more familiar. States also can lend important political support to a merger challenge where important constituencies within a state mobilize to endorse a transaction. 59

On other occasions, the federal antitrust agencies may regard state participation as an irritant. From the standpoint of case management, the presence of multiple public prosecutions can complicate the collection of evidence, the selection of case strategy, and the preparation of the complaint and supporting materials. The ability to pursue a case independently, or to seek additional relief, gives the states leverage in bargaining with DOJ or the FTC over the development of a case. The federal agencies would rather not be in the position of being second-guessed by another public prosecutor, whose

\footnotetext{
59 In 2008, the FTC sued to block a merger of two hospital systems in Northern Virginia. The acquiring firm (the Enova healthcare system) strove to enlist support for the merger from various groups within the state. The FTC's case might have encountered greater difficulty if the Virginia Attorney General had announced his support for the transaction. Instead, the Virginia Attorney General joined the FTC's complaint, providing the Commission with useful political cover to offset local opposition to the agency's intervention. In 2006, the FTC also benefitted from the decision of the Pennsylvania Attorney General to join an FTC action to block a merger of two natural gas distribution companies operating in the Pittsburgh metropolitan area. The Pennsylvania Attorney General's presence in the case helped blunt the argument of the merging parties that state action by a collateral regulator (the Pennsylvania public utility commission) immunized the merger from attack under the federal antitrust laws.
} 
demands might suggest that the federal agencies performed their tasks inadequately. ${ }^{60}$ The desire to achieve a common voice can lead to protracted inter-agency negotiations that would not occur if the federal agencies had exclusive competence to address matters of broad interstate significance. Divergent perspectives appear where the states disagree with the federal agencies on the application of substantive tests, and where a state desires to block a merger because the transaction may reduce employment within the state. 61

The parties to a merger must account for the possibility that one or more states will review their transaction and seek conditions that exceed the relief demanded by the federal antitrust agencies. Anticipating state opposition and identifying possible solutions are routine elements of merger planning by the companies and their advisors. Where possible, the merging parties will seek to enlist state governments as allies in the pursuit of a transaction before the federal authorities.

The US has not established a mechanism so substantial and formal as the European Competition Network to coordinate the work of the federal and state institutions. DOJ and the FTC have a formal liaison protocol with the states and engage in periodic conversations to discuss matters of common concern. The agencies occasionally have held workshops with the states on topics such as mergers in the petroleum sector and grocery retailing. Compared to the EU, the US mechanisms for coordinating activity and resolving frictions are substantially less comprehensive and more ad hoc in nature.

\section{Sectoral regulators at the National and State Levels}

Sectoral regulators often have independent authority, typically under a public interest standard, to review the competitive effects of mergers. Sectoral regulators at the

\footnotetext{
60 DOJ faces an additional complication, described below, when it brings a case in federal court to enjoin a merger and decides to resolve the case through a settlement. If DOJ files a case in federal court and later reaches a settlement with the parties, the district court must approve the settlement. State governments can seek and obtain standing to participate in the court's proceedings concerning a proposed DOJ settlement. On some occasions, states have used these proceedings to file objections to DOJ settlement proposals.

61 There have been a number of instances in which a state government has filed an antitrust case to oppose a merger for the stated purpose of preserving employment within the state. The federal antitrust agencies, by contrast, regard employment effects as irrelevant in making the decision whether to prosecute a merger.
} 
national level play key roles in the review of deals involving energy, telecommunications, and transportation. State public utility commissions play a similar role in reviewing energy and telecommunications transactions. Merger review by sectoral regulators usually takes place concurrently with proceedings before the DOJ or the FTC. The federal antitrust agencies and federal sectoral regulators have establishing working relationships to facilitate cooperation in the treatment of commonly reviewed matters. The merging parties account for federal and state sectoral oversight in merger planning and enlist specialized teams of external advisors to appear before the sectoral bodies.

The significance of multiple, concurrent oversight is perhaps most apparent in the case of telecommunications mergers. Take the simplified scenario in which DOJ and the FCC review a proposed transaction, such as AT\&T's effort to acquire T-Mobile. In that matter, DOJ reviewed the merger through the HSR process, and the FCC examined the transaction as part of its authority to approve the transfer of licenses necessary for the function of a telecommunications network. ${ }^{62}$ The parties cannot close the transaction and begin combined operations until they obtain both the DOJ and FCC approvals. The FCC is not subject to the HSR timetable. If it disapproves a transfer of licenses, the only legal recourse of the parties is to seek appellate review of the FCC's decision, a process that can take two to three years. The parties cannot complete the transaction during the appeal. This gives the FCC extraordinary power to demand concessions, and the pendency of the FCC proceedings gives DOJ additional time to prepare its own case.

In planning a transaction, the parties are aware of this interaction between sectoral regulators and the antitrust agency. It underscores a condition we raised earlier in discussing the consequences of the multiplicity of enforcement agents in the US system. No single agent has the capacity to preclude another agent from seeking more stringent remedies, or from obtaining a prohibition outcome. Thus, the enforcement agent with

\footnotetext{
62 The US telecommunications statutes require operators to obtain licenses to provide telecom services. Mergers typically require the merged entity to obtain FCC permission to transfer the licensings of the acquired firm to the acquiring entity. Until the FCC grants permission, the acquiring firm cannot operate the acquired firm's network.
} 
the most expansive preferences for intervention has the capacity to determine the outcome of a specific transaction, regardless of the decisions taken by other enforcement agents.

\section{Executive Departments}

In a number of instances, departments of the executive branch give the DOJ and the FTC their views about proposed mergers. The views of the Department of Defense (DOD), for example, play a major role in the decision of the federal antitrust agencies to challenge mergers involving defense contractors. DOD has no formal merger review mandate, but it does have the capacity to withhold approval for the assignment of its contracts from one firm to the newly merged entity. DOD support for a merger, and its willingness to testify in court in favor of a deal, generally would weigh against a DOJ or FTC decision to sue to stop a transaction. Parties contemplating a merger in the defense sector devote extensive effort to enlisting the support of DOD for the transaction.

There also are instances in which individual executive branch officials will make public comments about pending mergers. In some cases, high level officials publicly have endorsed a merger during the premerger review by the federal agencies. ${ }^{63}$ Such comments probably do not shape the decision to be taken by the antitrust authorities, but they draw additional attention to the merger and induce the agencies to exert additional effort to ensure that a chosen decision is well-supported. Even if DOJ and FTC do not heed the publicly stated demands of elected officials, such statements can diminish the effectiveness of the US merger review process by creating the appearance that external political pressure determines antitrust agency decisions in sensitive cases.

\section{Committee on Foreign Investment in the United States (CFIUS)}

In 1986, Congress adopted the Exon-Florio amendment to the Defense Production Act and created CFIUS to review mergers having important national security implications.

\footnotetext{
63 During the pendency of the Boeing/McDonnell Douglas merger, Vice-President Al Gore spoke before a rally at a Boeing Facility in Washington State and warned European officials against intervening to block the merger. Gore's speech appeared to anticipate that the FTC would approve the merger without conditions.
} 
Chaired by the Secretary of the Treasury, CFIUS has authority to recommend that the President bar mergers that threaten national security by, for example, placing sensitive defense research assets in the hands of foreign owners. DOJ and the FTC provide advice to CFIUS but are not members of the panel.

\section{Congress}

Across the spectrum of antitrust activity, mergers tend to attract the closest scrutiny from members of Congress. Soon after the announcement of a transaction, it becomes possible to make a quick, reliable judgment about short-term employment effects across the states in which the merging parties operate. Legislators in states that will gain jobs will urge federal antitrust officials to approve the transaction, and those in states that will lose employment will demand that the antitrust authorities oppose the deal. Members of Congress convey their views to antitrust agency leadership in letters and telephone calls. High profile deals often are the subject of congressional hearings during the pendency of a merger review before DOJ or the FTC. A key focal point of merger planning by the parties to a deal is to mobilize congressional support for the transaction and to assuage legislators who fear that the merger will have adverse employment effects in their constituencies. To build political support, companies sometimes will make public commitments to preserve existing jobs, to expand employment, or make new investments.

Intensified legislative scrutiny adds burdens to DOJ and FTC merger review, although it does not appear to alter policy outcomes. Both agencies must spend additional time responding to legislative requests for information and to participate in hearings. The FTC in the 1990s adopted a protocol that allows the Commission to give confidential briefings to senior congressional officials on the status of pending merger reviews. 64 The agencies also may devote greater effort to armor its findings against subsequent legislative criticism. Both agencies are aware that seeming indifference to legislative

\footnotetext{
64 DOJ has no such practice. The difference reflects the relatively closer ties that the FTC has with the Congress. The FTC is one of the federal "independent" regulatory agencies, but the independence consists of greater insulation from influence by the executive branch, not from the legislature.
} 
views can be punished in subsequent congressional deliberations about DOJ and FTC budgets.

As noted earlier, when the US agencies reach decisions consistent with the public exhortations of legislators, there will always be concerns that elected officials succeeded in pressing DOJ or the FTC to abide by their preferences. This can have serious consequences in a world where antitrust enforcement agencies in countries such as China carefully study developments in the United States. A sequence of demands by elected officials followed by a DOJ or FTC decision consistent with the legislators' demands can be taken as support for intervention by political branches of government in antitrust enforcement.

\section{Third parties}

Third parties have a notably different role in US merger review than they do in the EU process. US law confers no rights on third parties to have access to the file, nor do third parties have standing to sue to challenge a decision by DOJ or the FTC not to challenge a merger. With one limited exception, third parties also lack standing to challenge antitrust agency decisions to accept settlements that they regard as inadequate. The FTC is obliged to issue proposed settlements for public notice and comment. The comments of individuals and companies are placed on the public record. The FTC has virtually unlimited discretion to decline to adjust the proposed settlement in light of comments received. Third parties have no standing to contest the FTC's entry of a final order. The one exception, mentioned earlier, involves the Tunney Act, which requires federal court approval of DOJ proposals to settle pending federal court cases. Third parties may seek and obtain standing to comment upon DOJ settlement proposals during the Tunney Act proceedings. For example, a federal district judge must approve the DOJ settlement that allowed the merger of American Airlines and USAirways to proceed, subject to various divestitures. Various third parties have filed objections to the settlement in the Tunney Act proceedings before the district court. 
The absence of third party rights to contest agency decisions not to intervene (as well as the weak third party capacity to dispute proposed settlements) gives US antitrust agencies an important element of discretion that DG Comp lacks. When the US agencies decide to clear a merger, they do so with confidence that they will not have to defend their decision before a judicial tribunal. One consequence is that, compared to DG Comp, the US agencies can give greater effect to arguments (e.g., about entry and efficiencies) that do not lend themselves to rigorous proof but rest instead upon intuition and judgment accumulated through the examination of hundreds of transactions.

None of this means that third party participation in US merger review is unimportant. The agencies rely heavily on the views of customers in forming impressions about likely competitive effects, and rivals to the merging parties are seen as significant sources of information, notwithstanding their sometimes doubtful motives to oppose a merger. There also is a political feedback loop that third parties can use to get the agencies' attention as a surrogate for the right to challenge clearance decisions in court. Third parties (especially rivals to the merging parties) frequently go to members of Congress in the hope that a powerful legislator (e.g., the chair of a committee that oversees either DOJ or the FTC) will apply pressure to the agencies to take their arguments seriously. We note that these indirect means of pressing the antitrust agencies to take account of third party concerns generally lack the power - from DOJ or the FTC's point of view - of a credible threat by third parties to file a legal challenge.

\section{Advisors to the Parties}

The discussion above has indicated how parties to a proposed merger today engage the services of a wide array of advisors to assist in planning a transaction and navigating through the merger review process. A typical ensemble of external advisors for a significant merger will include: antitrust counsel, economic consultants, lobbyists to deal with executive branch agencies and Congress, and media consultants (who deal directly with journalists and engage academics and other commentators to say favorable things to the press about the merger). If the merger implicates the interests of a sectoral 
regulator or state governments, advisors proficient in dealing with the sectoral regulator and the state governments will be added to the group.

Among these groups, the antitrust bar and the economic consultants play a particularly important role in merger review. They ordinarily are repeat players who deal with the antitrust agencies in multiple deals each year. They closely study the comments and speeches of enforcement officials for hints of how specific deals will be evaluated. Relatively few law firms with a substantial US merger practice do not have offices in Washington, D.C. - a recognition of the importance of proximity to the regulators and the venues in which they regularly appear. They provide comments and participate in surveys that solicit opinions about the quality of the antitrust agencies. Their views factor heavily into annual ratings of agency quality prepared by publications such as the Global Competition Review.

The antitrust bar and economic consultancies form favorable (or unfavorable) assessments of a competition authority based on three factors. The first is the level of activity - either in the form of second phase inquiries or in the rate of intervention to block or qualify deals. If the agencies are not active in these respects, the income of external advisors falls. The second is the efficiency of the merger process, measured by speed of resolution, transparency, volume of information demands, and access to top decision makers. The third factor is the quality of substantive analysis, measured by predictability, clarity, and coherence. External advisors would prefer, of course, to see their transactions approved or cleared with relatively minor conditions. They understand that not all deals - least of all, highly concentrative transactions - will be or should be approved. What they regard as unacceptable are volatile agency policies and the refusal of top leadership to engage on key issues.

\section{Media Organizations}

Media reporting on merger review helps shape the impressions of observers outside the agencies about whether the agencies are performing well. Agency leadership is sensitive to negative reporting, and agencies devote considerable effort to position their programs 
to receive good coverage. The perceived imperative to obtain good coverage lead DOJ and FTC leadership to review the highest profile mergers, a consideration that complicates determinations of which agency will review specific transactions.

\section{THE COURSE OF A PROCEDURE}

\subsection{EU PROCEDURE}

When the Commission receives a notification which falls within the scope of the regulation ${ }^{65}$, it has to take one of the following decisions within a period of 25 working days $^{66}$; (i) that the proposed concentration does not raise serious doubts regarding its compatibility with EU law (Art. 6.1(b) of the Commission Regulation 139/2004) or (ii) that the concentration raises doubts regarding its compatibility and that, to this effect, proceedings (6.1(c)) must be initiated.

A decision under Art. 6.1 (b), which might involve commitments, is colloquially referred to as a 'Phase I' decision; a decision under Art. 6.1(c) triggers a 'Phase II' investigation and decision ${ }^{67}$.

If proceedings gave been initiated (as per Art. 6.1(c)), then the Commission has to take one of the following decisions within a period of 90 working days: (i) declare the merger compatible with EU law under Art. 8.1; do the same following acceptance of suggested modifications to the notified merger (Art. 8.2); or declare the merger incompatible (Art. 8.3). The deadline is automatically extended by fifteen additional days if remedies have been offered (before day 55 of the second phase) which could remove doubts regarding the incompatibility of the notified merger with EU law.

\footnotetext{
65 No merger can be consummated unless the Commission has decided one way or the other (Art. 7 of Regulation 139/2004).,

66 This period can be extended by 10 working days if the parties submit remedies (Art 10.1 of the implementing regulation), as further discussed below.

67 A phase II is opened in less than $5 \%$ of the notified mergers (see www.ec.europa.eu/competition/mergers/statistics.pdf). The frequency of second requests in the US is similar (see Hart-Scott-Rodino Annual reports, available at www.ftc.gov)
} 
Importantly, the Commission thus has to justify both intervention as well as non intervention. The Court has also clarified that the standard of proof is the same for clearance (with or without remedies) and prohibition ${ }^{68}$ in Phase II.

Before issuing a decision under Arts. 8.2, 8.3 or 8.4, the Commission must first consult (but does not have to defer to) the Advisory Commission on Concentrations. It must address its objections to the notifying parties and make them available to other involved parties, and must set a deadline in order to receive comments (Art. 13 of Implementing Regulation 802/2004).

In order to undertake its investigation, the Commission has some statutory powers, to issue information requests (Art 11 of the Implementing Regulation), to undertake dawn raids (Art 13) and to impose fines (Art 14) or to "stop the clock" (Art. 9) in case of noncompliance.

In principle, the Commission thus follows a two-stage procedure; it is meant to undertake a preliminary investigation during the first phase, to filter out the merger that are clearly not problematic on this basis and to investigate further those mergers that may be problematic 69 .

The Commission is also subject to strong transparency requirements. In terms of ex post transparency, the Commission is under the obligation to publish detailed final decisions. Regarding ex ante transparency (during the procedure), the Commission has to spell out its objections in detail and may decide to provide a non-confidential version of its objections to third parties. The Commission will also have to support its decision to open a second phase investigation (Article 6(1)(c)). The Commission has occasionally provided a non-confidential version of this decision to third parties (but has no obligation and is not otherwise committed to do so). The evidence gathered by the

\footnotetext{
68 See Vesterdorf, B., (2005) Standard of proof in merger cases: reflections in the light of recent case law of the Community Courts, European Competition Journal, 3, P1ff

69 The original merger regulation did not explicitly allow for remedies in Phase I (see Neven, Nuttal and Seabright,1994, see footnote 9). This possibility has been introduced in 1997 (Regulation 1310/ 1997).
} 
Commission in the market investigation is only made available to the notifying parties and only after the Statement of Objections ${ }^{70}$. The comments gathered in the context of the market test of remedies are not made public (although a summary is provided to the parties).

\subsubsection{Pre-notification}

According to the 'Best Practices on the Conduct of the EC Merger Control Proceedings' (BP I) ${ }^{71}$, the rationale for pre-notification is to make optimal use of the short statutory limits that the Commission must observe when notified of a proposed merger ${ }^{72}$. This is an option that is offered to the parties as well as other interested parties ${ }^{73}$, although it remains at the discretion of the Commission.

Pre-notification discussions ${ }^{74}$ can be used to delineate the information that will be required throughout the process following formal notification of the proposed merger ${ }^{75}$ : Pre-notification discussions are also meant to identify the quantitative data that the Commission will require ${ }^{76}$.

\footnotetext{
70 According the 'Best Practices on the Conduct of the EC Merger Control Proceedings', the Commission may share some information before the $\mathrm{SO}$ and has occasionally done so.

71 Note that neither these best practices, nor the 'Best Practices for the Submission of Economic Evidence and Data Collection in Cases Concerning the Application of Articles 101 and 102 TFEU and in Merger Cases' also issued by DG Competition (hereinafter 'BP II') is legally binding. For instance, BP I§4 states without ambiguity that BPs “do not create or alter rights and obligations as set out in the merger regulation" These documents are nonetheless relevant, since they reflect the point of view of the authority entrusted with enforcing the merger regulation.

72 According to BPI, the aim is to make the "short time available in EC merger procedures as productive and efficient as possible". 73 As indicated by the Merger Regulation (Commission Regulation 139/2004), and its implementation regulation (Commission Regulation 802/ 2004). For instance, the Preamble of the latter states that (\$11) "the Commission shall give the notifying parties and other parties involved in the proposed concentration, if they so request, an opportunity before notification to discuss the intended concentration informally and in strict confidence".

74 See Annex 1 of Regulation 802/2004 (\$1.1)

75 According to Annex 1 "pre-notification contacts are extremely valuable to both the notifying parties and the Commission in determining the precise amount of information required in the notification and in the majority of cases, will result in a significant reduction of the information required. Notifying parties may refer to the Commission's best practice on the conduct of EC merger control proceedings, which provides guidance on the pre-notification contacts and the preparation of notifications".

76 In BP II at §76, the Commission indicates that: "In the case of mergers, prenotification discussions should routinely deal with data issues. Although the Commission will endeavour to identify all issues that may require a Data Request as soon as possible, certain issues may not be identified until later in the proceedings".
} 
However, the pre-notification process goes much beyond a mere preparation of the information required for notification ${ }^{77}$. It is rather a period during which the Commission expects to complete a significant part of its investigation and during which the parties can make substantive submissions on the theories of harm, its validation and on potential efficiencies. Anecdotal evidence also suggests that in (potentially) complex cases, pre-notification can last several months, and involve a number of meetings with the parties as well as several substantive submissions ${ }^{78}$.

A number of features of the investigation taking place during pre-notification can be highlighted. First, during pre-notification, the Commission has no formal power of investigation, e.g. it has no statutory basis to request information and enforce its requests, and/or to draw inferences from non-cooperative behaviour. This may matter for the balance of proof taking: as mentioned above, the Commission indicates that it will have contacts with other interested parties during pre-notification. In practice, the Commission is more likely to be responding to requests for meetings than initiating contacts with third parties, so that the range of its sources of information will be biased towards those having a strong interest in the case and requesting meetings with the Commission to this effect.

In addition, even if the Commission seeks information, parties may not have the same incentive to cooperate in providing information to the Commission. The bias against information from parties that have little direct interest in the case will thus not be

\footnotetext{
77 Note that pre-notification is encouraged even in cases where concerns regarding the proposed merger are unlikely: to this effect, Annex 2 of Implementing Regulation 802/2004 (entitled 'Importance of Pre-notification Contacts') refers to the 'short form notification' (CO), which may be used for concentrations that are unlikely to raise significant issues. The Commission encourages the parties to discuss the merit of a short form in pre-notification among other reasons because one of the parties might have underestimated the degree of complexity involved. §1.3 of Annex 2 of Implementing Regulation 802/2004 indicates that: "experience has shown that pre-notification contacts are extremely valuable to both the notifying parties and the Commission in determining the precise amount of information required in a notification. Also, in case where the parties wish to submit a short form notification, they are advised to engage in pre-notification contacts with the Commission in order to discuss whether the case is one for which it is appropriate to use a short form. Notifying parties may refer to the Commission's best practice on the conduct of EC merger control proceedings, which provides guidance on the pre-notification contacts and the preparation of notifications". In a similar vein, BP I in $\S 5$ (echoing Annex 2 of the Implementing Regulation) underscores that pre-notification should not be limited to 'difficult' cases, since it is often difficult to decide ex ante the degree of difficulty involved in a specific transaction: "DG Competition finds it useful to have pre-notification contacts with notifying parties even in seemingly non problematic cases. DG Competition will therefore always give notifying parties and other parties involved the opportunity, if they so request, to discuss an intended concentration informally and in confidence prior to notification".
}

78 For instance, in the recent UPS/ TNT and Olympic/ Aegean transactions, pre-notification lasted for more than 3 months. 
addressed by the informal information requests that the Commission might contemplate.

Second, during pre-notification, the Commission is not bound by the procedural requirements and best practices of the formal investigation process. For instance, the Commission does not have to take minutes of a meeting that it has had with interested parties; even if the Commission does so in some instances, the fact that there is no requirement to this effect involves discretion that could be abused. There is also no guarantee with respect to the exercise of internal checks and balances on the investigation; the case would normally be discussed at the (weekly) merger management meeting and the support of the Chief Economist could be sought. But here again, the case team (and its hierarchy) enjoys more discretion than during the course of the formal investigation.

Third, the informal character of the investigation might affect the substance of proof taking. In the informal, pre-notification environment, evidence submitted by the parties cannot be held against them, as there are no legal consequences flowing from these exchanges, even if self-incriminating evidence has indeed been provided. One could contemplate nevertheless that the Commission might use self-incriminating information received during pre-notification to make its determination; given that the Commission enjoys significant discretion, it does not have to reveal in a formal decision all the sources of the information that it has used in order to form its judgment. The parties will understand that to a point, but at the margin will still be less careful in revealing potentially self-incriminating evidence than they would be during the formal procedure.

This is particularly likely to be the case because pre-notification discussions often take the form of free flowing discussion in which executives take part (as encouraged by the Commission). Executives will naturally be less aware of the consequences that the information they reveal might have on the Commission's view of the case (if anything because they will be less aware of the Commission's standards), and will be more likely to inadvertently pass on information that may prove unhelpful to their case. 


\subsubsection{Phase I}

According to the merger regulation (Art. 5 of Regulation 139/2004), the notification becomes effective, and the clock starts ticking, only when the Commission considers that the notification is complete (a determination over which the Commission has wide discretion) 79 . The form $\mathrm{CO}$ is extensive and together with its annexes, it may run over hundreds of pages.

During this phase, the Commission starts the formal investigation and needs to take a decision within 25 working days. As mentioned above, after 15 working days, the Commission is meant to communicate to the parties whether it has concerns with the proposed concentration in the context of a state of play meeting. The parties can then decide to offer remedies, in which case the time allowed for Phase I is extended by ten working days. At the end of Phase I, the Commission can accept the proposed concentration, accept the concentration subject to undertakings or issue a decision expressing serious doubts about the proposed concentration and open a second phase investigation.

The Commission is supposed to open a second phase investigation if it has "serious doubts" about the effects of the merger. If accepted, the remedies thus have to remove these serious doubts. It is not entirely clear what is meant by "serious doubts" as a criteria for decision making, but one can anticipate that serious doubts refer to a significant probability that the merger might turn out to be anti-competitive. Importantly, this means that the Commission will evaluate remedies differently in Phase I and Phase II. In Phase II, the Commission is supposed to clear the merger if it is more

\footnotetext{
79 Art. 5 of Regulation 139/2004 stipulates: "Subject to paragraph 2, 3, and 4, notification shall become effective on the date on which they are received by the Commission".. \$2 reads: "where the information, including documents, contained in the notification is incomplete in any material respect, the Commission shall inform the notifying parties or their representative in writing without delay. In such cases, the notification shall become effective on the date on which the complete information is received by the Commission". §4 reads: "incorrect or misleading information shall be concerned to be incomplete information".
} 
likely than not that the merger will not be anticompetitive, or to accept remedies such that it is more likely than not that the merger will not be anti-competitive ${ }^{80}$.

\subsubsection{Phase II}

In what follows, we discuss three aspects of Phase II, namely the organisation of the hearing, the organisation of the panels and the discussion of remedies.

As mentioned above, the Hearing Officer is responsible for the organisation of the hearing. He chairs the meeting during which the Commission presents its case (as laid out in the Statement of Objections and the parties present their response. Interested parties may also be allowed to make an oral presentation. Time is scheduled for questions. Given the format, these questions are mainly addressed by the Commission to the parties (as the parties' response to the SO is normally included in their presentation). Given the time constraints (one or at most two days), the presentations also remain relatively general and there is no exchange of detailed arguments and counterarguments between the Commission and the parties, let alone between the parties and the third parties. This is reinforced by the passive role of the Hearing Officer with respect to substance, as he merely ensures that the schedule is adhered to and might occasionally ask a question to the parties but does not direct the debate (as a judge would do). Overall, the hearing is thus mostly an opportunity for the Commission and the parties to present their case to a different audience, namely the Legal Service, the cabinet of the Commissioner, the member states and the associated services. There is no cross-examination of the arguments.

The Commission may also decide to organise a panel, often after the hearing ${ }^{81}$. This is a purely internal procedure, managed by the policy directorate, in which a team of civil

\footnotetext{
80 In the recent appeal of the Microsoft/ Skype clearance, the Court has indicated that the standard of proof for clearance in Phase I is the same as in Phase II. However, the pronouncements, which does not give effect to the difference between serious doubts and the balance of probabilities is hard to square with the wording of the Merger Regulation. (case T79/12, Judgment of the General Court, 11/ 12/ 2013). For a discussion of the issue (and a comparison with the US), see Langus, G., V. Lipatov and D. Neven, (2014), Phase II vs Second Request, A comparison of EU and US merger control procedures, mimeo
} 
servants who have not been involved in the case previously (so-called "fresh pair of eyes") reconsiders the evidence and writes a report which discusses options, knowing that at that stage, DG COMP is most likely to have crystallized its position. The report may openly challenge some of the evidence and its evaluation by the case team in support of a particular course of action, or it may point to possible weaknesses that the case team should address in the final decision. The report of the panel is presented and discussed with the case team in the presence of the Legal Service and Chief Economist Team. Discussions can be animated and some proposed decisions are known to have been seriously amended at that stage. It is however a mechanism of checks and balances which suffers from a couple of shortcomings (besides the fact that its results are not publicly available). First, the incentive of the members of the panel to openly challenge their colleagues may be affected by the prospect that the tables may turn and that they might themselves be in the position of being openly challenged by their colleagues. Second, there is no guarantee that a panel will be organised, as it remains at the discretion of the senior management. In a potentially difficult case which calls for delicate judgement, but for which there may be a strong prior in favour of a particular course of action, the internal debate can thus be avoided altogether.

As mentioned above, the parties can propose remedies at any stage in the procedure and the deadline is extended by 15 working days if the parties propose remedies before day 55. The Commission will then decide whether to market test the remedies and will only do so if they anticipate that the proposed remedies may be adequate. If the market test is not supportive, the Commission will communicate this to parties, who can then submit an improved package. Several rounds of remedies and market tests can take place before a final decision is made by the Commission. There are at least two features of this process that are worth mentioning. First, there is typically a greater involvement of the senior management of DG Competition and of the Commissioner at this stage of the procedure. This is normally also mirrored by a greater involvement of the very

\footnotetext{
81 Panels can be organised after the response to the SO (in the absence of a hearing). On rare occasions, panels have also been organised before the SO.
} 
senior management of the parties. These constituencies naturally do not have a knowledge of the file as detailed as that of other constituencies, in particular the case team. They will also consider a range of aspects for the resolution of the case that go beyond the calibration of remedies that would address the harm that has been identified. As a consequence, the remedies phase is better described as a "negotiation" than a calibration of remedies. Second, the Commission tends to rely primarily on the market test in order to assess remedies. The respondents to the market test however respond to diverse incentives; they may have incentives to derail the transaction, they may be involved in negotiation with the parties for the purchase of divested assets, or may want to ensure that an asset that they would like to buy is included in the remedies packages; they may also be involved in negotiations with the parties on unrelated issues and may want to leverage their position in the remedies process with respect to that negotiation. The Commission is of course well aware of the fact that respondents may act strategically but it is difficult for the Commission to evaluate how the input from the respondents should be discounted without understanding their motivation. This makes the negotiation of remedies potentially prone to capture by the respondents or by the Commission, which has discretion in the weight that it attaches to the responses and may use the responses to the market test to pursue its own goals ${ }^{82}$. As mentioned above, the fact that that responses to the market test are not made public enhances the scope for capture.

The deadlines for the completion of Phase II also act as binding constraints on the investigation. This arises in particular because of the time that needs to be reserved at the end of the procedure for the decision by the college of Commissioners (two to three weeks), for the consultation of the member states (another two weeks) and the consultation of the associated services (another week at least). Hence, the position of DG COMP/ the Commissioner regarding the anti-competitive effects needs to crystallize well before the deadline (approximately 60 days, or two-thirds of the way, into Phase

\footnotetext{
82 It is also worth noting that quantitative methods that have been used in the course the proceedings, like merger simulations or price concentration analysis, are rarely used for the negotiation of remedies. Yet, these methods could help, for instance in delineating the scope of divestments that may be necessary to avoid a significant price increase.
} 
II). Even if discussions on remedies may be undertaken in parallel with the consultation of the associated services and the member states (and sometimes even with the consultation with the cabinets of the other Commissioners), the (largely formal) consultation and decision making process within the Commission significantly reduces the time available for the substantive analysis.

\subsection{US MERGER CONTROL}

In 1976, Congress adopted the Hart-Scott-Rodino Antitrust Improvements Act and set the modern foundation for the US merger review process. ${ }^{83}$ The HSR statute created notification obligations for parties undertaking mergers above certain size thresholds and imposed mandatory waiting periods to allow DOJ and the FTC to decide whether to go to federal court to seek preliminary injunctions to block anticompetitive deals. HSR transformed US merger review from a regime of ex post litigation to an ex ante regulatory mechanism that relies heavily upon negotiation between the merging parties and the agencies.

\subsubsection{Pre-notification Phase}

Compared to practice in the EU, the US regime features less discussion between the parties and the agencies before the formal pre-merger notification documents are filed. A major historical impediment to pre-notification consultations has been the concurrent authority of DOJ and the FTC to review mergers. Under the HSR Act, detailed review of a transaction may be carried out by one agency only. This condition requires the agencies to decide which institution will carry out the review. As noted below, for a significant category of transactions, the two agencies engage in intense and sometimes protracted struggles through the clearance process to determine which body will review a deal.

\footnotetext{
83 Pub. L. No. 94-435, 90 Stat. 1383 (1976). The HSR premerger notification provisions appear in Section 7A of the Clayton Act, which is codified in 15 U.S.C. § 18a. On the origins and consequences of the 1976 reforms, see Symposium: Twenty Years of HartScott-Rodino Merger Enforcement, 65 Antitrust LawJ ournal 813 (1997).
} 
The uncertainty in some cases over the identity of the reviewing agency makes it difficult for the parties to begin discussions with the federal enforcement authorities before notification takes place. Where the resolution of the interagency clearance process is uncertain, the only way to carry out pre-notification consultations is to discuss the transaction with both agencies. Most parties (and the agencies) regard this as excessively cumbersome, and they do not pursue this option.

Modern practice displays a trend away from the historical norm of limited prenotification discussions. There always have been categories of transactions for which the identity of the reviewing federal agency could be predicted with confidence. As described further below, the chief basis for interagency clearance is the relative levels of experience the agencies have obtained with a sector in the past few years. There are some sectors for which one agency has an overwhelming advantage in experience, and there is no question but that a specific agency will continue to review mergers in that sector. For example, the FTC has reviewed all mergers involving pharmaceutical companies for a period reaching back over several decades. Similarly, DOJ has reviewed all mergers involving mining, such as coal production. In still other cases, limits on the jurisdiction of the FTC ensure that certain transactions (e.g., those involving the telecommunications sector) always will be examined by DOJ .

The trend toward greater pre-notification discussions in the US also has been inspired by efforts to align the timing of the EU and US processes more completely. This promises to have the effect of extending the pre-filing component of the US process as parties engage DOJ and the FTC in the rough equivalent of pre-notification consultations in the EU. This development may align the timing and substance of the EU and US reviews more closely, but at the possible cost of extending the time needed to complete the review of specific transactions. In one sense, the front-loading of analysis embodied in the EU regime might be joined up with the back-loaded analysis in the US system.

A growing tendency in recent years is for parties to transactions involving sectors in which one agency has clearly established merger review "property rights" is to approach 
the agency before notification to begin discussions about a proposed transaction..$^{84}$ The purpose of these consultations is to alert the agency to a pending deal and to engage on issues that are likely to be significant to its resolution. The trend is most noticeable in sectors in which the parties are relatively regular repeat players with the agency. In the pharmaceutical or petroleum sectors, for example, the main industry actors appear somewhat regularly before the FTC in discussions about mergers or other matters. The agency case handlers have extensive familiarity with the sector, and pre-notification consultations can enable the agency to focus more promptly on potential questions and speed the ultimate resolution of the merger review.

As suggested above, this form of pre-notification consultation is not feasible for sectors in which both federal agencies have a claim to possess superior expertise (by reason of recent experience) and are likely to squabble over which institution will conduct the HSR review. This element of uncertainty denies the US system the same flexibility parties enjoy in the EU to meet with case handlers to describe possible transactions, explain the rationale for such deals, and to identify potential problems. Were it not for dual federal enforcement, one would expect the US to use pre-notification consultation discussions to a greater extent than we see today.

Some parties use the pre-notification period to take actions that anticipate potential competitive problems and purport to cure them. In a horizontal merger, one preemptive tactic is to identify potentially problematic competitive overlaps and to divest assets in advance of filing the notification documents. This has the potential advantage of expediting review of the transaction, as the offending overlaps have been eliminated. The difficulty with this form of advance positioning is that it requires the companies to make an accurate prediction of what the agencies and, ultimately, the court will see to be the competitive problem and a correct assessment of what the same bodies will view to be a suitable cure. Prepositioning of this type will not expedite the government's review of the merger if the antitrust agency concludes that the parties

\footnotetext{
84 Experienced merger practitioners in law firms have compiled lists that identify which agency is likely to review transactions in specific sectors. In many instances, these lists supply a reliable basis for predicting for clients which agency will review their deal.
} 
underestimated the severity of the competitive problems and demands solutions that exceed the divestitures the parties already have executed.

A less drastic form of prepositioning is for the parties to identify a package of remedies that they would be willing to accept to resolve competitive issues. Some parties in the US have entered the notification process by announcing their intention to divest specific assets or make other commitments when the merger is carried out. Parties have made these commitments in the expectation that if DOJ or the FTC decided to contest the merger in court, they would be able to tell the court that they already have crafted a reasonable solution, and only the intransigence of the enforcement authorities stands in the way of a suitable resolution. The ability of a court to impose this type of "fix-it-first" solution upon the agencies, by entering an order that binds the parties to carry out proposed remedies, is a matter of considerable controversy.

\subsubsection{Notification and Waiting Period}

The HSR regime requires parties to give advance notice to DOJ and the FTC of transactions exceeding certain thresholds based upon the size of the parties.85 Filings are made with the FTC, which is the agency designated by the 1976 statute to administer the notification program. The required HSR filing is considerably more austere than the filing required by the European Commission. The HSR form requires basic information about the business operations of the merging parties and, perhaps most significantly, obliges the parties to submit all documents that discuss plans for the merger. These materials, referred to as " 4 (c)" documents, 86 contain the firms' internal planning materials, presentations made to the board of directors, and white papers prepared by external advisors, such as investment bankers. It is not unusual for 4(c) documents to contain comments about the likely competitive consequences of the transaction. DOJ

\footnotetext{
85 Failure to comply with the reporting requirements can subject the parties to substantial civil monetary penalties, as well as a judicial order that rescinds completed transactions and compels the disgorgement of any profits earned after the merger was completed.

86 This corresponds to the specification on the HSR reporting form.
} 
and FTC case handlers regard such materials as an important starting point for evaluating the proposed deal.

Upon the filing of the HSR form, the federal authorities have 30 days to decide whether to commence a second-phase inquiry - to issue what in HSR jargon is called a "second request"87 - or to allow the transaction to proceed without challenge. The initial 30-day waiting period can yield varied outcomes. If the agencies do not issue a second request, the parties may proceed to close the merger. As noted earlier, a decision to take no action is not subject to judicial challenge - for example, by an aggrieved customer or competitor of the parties. A decision by the federal agencies not to intervene does not preclude the government from challenging the transaction at a later date. For purposes of business planning, the running of the 30-day period constitutes a relatively confident basis for expecting that no future government challenge will be forthcoming. Only in rare cases have the federal agencies allowed the initial 30-day waiting period to lapse and later sought to unwind a completed merger. ${ }^{8}$

A second scenario is that the parties, in submitting the HSR notification form, request "early termination,"89 and the antitrust agency concludes its review well before the 30day waiting period has closed. This approach is used for reportable transactions that are almost certain not to pose competitive problems. Parties typically are cautious in seeking recourse to this mechanism and ask for early termination only in relatively clear instances in which the merger presents no plausible theory of competitive harm.

A third scenario, discussed in more detail below, is that the reviewing agency issues a second request. It is possible for the parties to seek to forestall this result by immediately acknowledging potential competitive problems and coming forward with remedial proposals to resolve them. Such offers usually would be accompanied by a

\footnotetext{
${ }^{87}$ The waiting period is shorter for hostile tender offers.

88 This unusual scenario took place in the FTC's Evanston hospital merger case. The Commission took no action when the parties made their HSR filing but later brought a case alleging that the transaction was anticompetitive.

89 The HSR reporting form has a box that the parties can check if they desire early termination.
} 
commitment to extend the duration of the first phase inquiry to allow time for the remedial proposals to be assessed properly.

The federal agencies have authority to accept remedies offered during the initial phase inquiry and forego recourse to a second-phase review. In practice, the case handling teams at DOJ and the FTC generally will insist on having access to company records and to conduct interviews to determine whether the parties have correctly identified the full dimensions of the competitive problems and have offered a sufficient solution. This caution ordinarily leads the staff to insist on some form of second-phase inquiry, albeit a limited one if the parties have diagnosed the problems accurately and made a generous offer to solve them.

A fourth scenario is that the two agencies dissipate most of the initial 30-day waiting period by quarreling over which agency has a superior claim to "clearance." As recounted earlier, such disputes are not routine. Yet they happen often enough to raise questions about the wisdom of the dual enforcement structure. Contentious disputes arise most often where technological developments are causing two previously distinct sectors to converge, and each agency stakes a claim to superior expertise in what has become an amalgam of two sectors. The US agencies derive prestige, recruiting advantages, and budget resources according to how often they are perceived to be major players in matters of great importance. Mergers of well-known producers of consumer goods, in particular, tend to be high profile matters and are widely reported in the popular media. DOJ and FTC have strong incentives to claim property rights over these matters, and disputes over such transactions can be ferocious.

If an impasse consumes most of the 30-day initial waiting period, it is almost certain that the agency which receives the file will ask the parties to "pull and refile" their notification (to provide the agency another thirty days to do what it ought to have done in the first thirty days) or to face the certainty of a hastily assembled, boilerplate second 
request. Faced with this irksome demand, the parties usually capitulate by pulling and refiling the notification. 90

DOJ and the FTC have used a number of methods to resolve clearance disputes expeditiously. Means to this end have included flipping coins, using a "possession arrow" that assigns the next disputed matter to the agency that lost the previous one, and engaging external mediators in a form of alternative dispute resolution. All of these have proven to be prone to either gaming by the agencies or considerable delays. In 2002, the two agencies agreed to reforms of the clearance mechanism by reallocating specific sectors and establishing a new mechanism for resolving disputes. DOJ abandoned the agreement after Ernest Hollings, a powerful member of the US Senate, made a credible threat to reduce the department's budget by ten percent and pursue various forms of retribution against the FTC. Hollings perceived that the proposed reallocation of sectors would reduce incentives of firms in the media and entertainment sectors to contribute to his election campaigns and provide other forms of homage.

\subsubsection{Second Phase Inquiries: The Second Request}

Upon receiving a second request, the parties have the opportunity to negotiate limitations with the antitrust agencies. It is common practice for DOJ and the FTC to eliminate certain specifications or narrow others. Even with these modifications, claims of agency overreaching and insensitivity to the costs of document collection and production appear regularly. Without trying to resolve debates about the scope of second requests, there is broad agreement that the second request process can be expensive, especially in complex transactions.

The extensive nature of second request document demands reflects a core element of US merger review. Compared to their European counterparts, the US agencies rely more heavily on documentary records. The US agencies also supplement documents with

\footnotetext{
90 The US imposes a filing fee for HSR reporting. Congress established this mechanism in the 1990s as a budget gimmick to avoid reliance on appropriated funds. When a party pulls and refiles its HSR notification pursuant to an agency request, the government generously waives the filing fee for the second filing.
} 
extensive investigational interviews with company officials and third parties. As a result, the second phase of US merger review tends to be more extensive than second phase inquiries in the EU. As noted earlier, neither the parties to the merger nor third parties (e.g., rivals who raise complaints with the government authorities) have rights of access to information the agencies collect in the second phase inquiry.

When the parties have submitted information required by the second request, an officer of the merging parties certifies compliance to the antitrust agency. The certificate of compliance triggers a final 30-day waiting period in which the agency must decide to seek a preliminary injunction in court, to allow the transaction to proceed unscathed, or to accept a settlement with the merging parties. The final 30-day period can be extended by agreement of the agency and the parties. Extensions are commonplace, especially for complex or controversial deals. Parties also routinely enter "timing agreements" by which they promise to give the agency a specific amount of notice before they close a transaction.

The possibilities for extensions of the final waiting period give the US regime its famous and hotly debated elasticity on the back end of the merger control process. The agencies can exercise powerful leverage by telling the parties that, unless extensions are forthcoming, they will file a complaint for a preliminary injunction in federal court. Parties who wish to avoid the turmoil - within their organizations and with investors of being subject to a preliminary injunction action frequently acquiesce in requests for extensions.

\subsubsection{Agency Decision to Intervene}

Case handling teams of attorneys and economists perform the initial analysis at the DOJ and the FTC. They operate in "shops" (the FTC jargon) or "sections" (the DOJ vocabulary) that are organized either by activity (e.g., merger specialists) or by sector (e.g., health care). The case handlers have considerable power to frame the analysis. Once a case develops substantial momentum within the case handling team, it can 
require great effort and fortitude by higher levels of management (often, political appointees who are wary of creating antipathy with careerists) to slow down the train.

Case handler recommendations proceed through at least two levels at DOJ - to intermediate managers at the section level, and then to the "front office" consisting of the Assistant Attorney General for Antitrust, his senior deputies, and his own advisors. The parties usually have an opportunity to make presentations to each decision maker in this chain. At the FTC, the recommendation proceeds from the section level to the office of the Director of the Bureau of Competition to the five commissioners. At both DOJ and the FTC, the economists' unit submits its own recommendation to agency leadership. This device provides an important element of quality control at both agencies. This does not mean that contrarian advice from the economists is invariably heeded. It does ensure that doubtful reasoning by the lawyers is exposed and debated before the decision to prosecute takes place.

One possible outcome of the decision making process is that the agencies decide to take no action. Such decisions are unreviewable in the courts. A second outcome is that the parties and the agencies reach a settlement. FTC settlements are issued in preliminary form for notice and public comment. The FTC is not obliged to heed comments submitted, and third parties have no standing to contest the agency's decision to ignore comments. DOJ settlements are subject to Tunney Act review, which entails participation by interested parties in federal court proceedings to approve the settlement. The district judge to whom a case is assigned must approve the settlement before it takes effect.

\subsection{DECISION ON LIABILITY}

Neither DOJ nor the FTC has power to issue prohibition decisions. Only the federal courts can enjoin mergers which the agencies believe to be anticompetitive. This gives the parties an important element of leverage in their negotiations with the agencies. The parties know that they will have the opportunity to present their case to a neutral third party judicial tribunal, and the tribunal's views are controlling. 


\section{CONCLUSION}

Our review of EU and US procedures and institutions for merger control reveal a different ecology. EU and US procedures differ in terms of their basic design and in terms of the procedures that are naturally associated with these alternative designs. On the one hand, there is a single investigator and decision maker operating under a symmetric mandate in the EU and on the other hand, an investigation and settlement operating under the threat of a court decision in case of challenge only in the US. The differences that we observe in terms of procedural rights can also be related to these basic designs. The EU has developed numerous procedures (state of play meetings, transparency of the evidence, Statement of Objections, hearings, strict deadlines) and has granted extensive rights to the parties in the context of these procedures in order to provide some guarantee that the Commission's role as investigator and decision maker at first instance is not abused. In addition, the DG COMP being part of the Commission, some formal rights have been granted to other services. As merger control is a competence that has been granted by the member states, some rights have also been granted by the member states to oversee the enforcement decisions. Overall, the EU procedure involves many constituencies with formal rights, but not necessarily with great influence. By contrast, the US procedures appear to be rather informal, the balance in the investigation and evaluation of the merger being provided by the credible threat of a court decision.

The role that other parts of government play in these different environments can also naturally be related to broader institutional constructions. With a strong federal government that has extensive competences for regulation, merger control on competition grounds is subject to the additional public interest test of regulators in the US. Such additional control is weak in the EU, which has more limited competences for regulation (notably for telecoms and transport). In addition, both the executive and the legislative powers are more fully developed at the federal level in the US (by comparison with the EU, in which the executive powers are shared between the European Council 
and the Commission and in which the European Parliament has a more limited role than the US Congress). Both the executive power (in particular through the nomination of the members of the FTC and Assistant Attorney General for Antitrust) and the legislative seem to be in position to wield greater influence on enforcement in the US than is the case in the EU.

Overall, one cannot help wondering whether such different systems of merger controls produce different outcomes and how they interact. Whether they produce different outcomes in similar cases is not a matter on which we take a view. While there is an argument that US procedures have proved lenient (see Kwoka, 2012) and while this resonates with the asymmetric nature of merger control in the US, there is no comparable evidence for the EU. Clearly, developing such evidence would be particularly insightful.

Regarding the interactions between the two procedures on merger that are reviewed in both jurisdictions, there is a now a great deal of cooperation among the agencies, a concern about divergent outcomes and ostensible satisfaction from common positions (see Deisenhofer, 201391). Still, a variety of situations can arise. In some instances, one agency may want to pre-commit and clear in the merger before the other agency has had an opportunity to complete its review, thereby possibly affecting the outcome. For instance, the DOJ closed its investigation on the Oracle/ Sun merger ${ }^{92}$ a few days before the Commission opened its second stage investigation. In other instances, one agency may delay its review, anticipating that it will be easier for the other agencies to request appropriate remedies (Cisco/ Tandberg ${ }^{93}$ and Intel/ McAfee ${ }^{94}$ could be seen in this light). Given the greater flexibility that they enjoy in terms of timing, the US agencies may also have a strategic advantage in these interactions and the merging parties can of course affect the interactions through an appropriate timing of notification.

\footnotetext{
91 See footnote 36

92 Case M5529

93 Case M5669

94 Case M5894
} 
